\title{
Immunomodulatory Effect of Virgin Coconut Oil in Wistar Rats Infected with Staphylococcus aureus
}

\author{
Widianingrum DC ${ }^{1}$, Salasia $\mathrm{SIO}^{2}$ \\ ${ }^{1}$ Department of Animal Science, Faculty of Agriculture, University of Jember, 68121 Jember, Indonesia \\ ${ }^{2}$ Department of Bioresources Technology and Veterinary, Vocational College, Universitas Gadjah Mada, 55281 Yogyakarta, Indonesia \\ *E-mail: isrinasalasia@ugm.ac.id
}

(received 30-11-2020; revised 04-02-2021; accepted 11-04-2021)

\begin{abstract}
ABSTRAK
Widianingrum DC, Salasia SIO. 2021. Peran Imunomodulator Virgin Coconut Oil pada Tikus Wistar yang diinfeksi dengan Staphylococcus aureus. JITV 26(1): 31-38. DOI: http://doi.dx.org/10.14334/jitv.v26i1.2670.

Virgin coconut oil (VCO) mengandung bahan aktif yang dapat meningkatkan imunitas tubuh terhadap agen penyakit. Penelitian ini bertujuan untuk mengetahui efek imunomodulator VCO berdasar tinjauan aktivitas superoxide dismutase (SOD), proliferasi limfosit, gambaran histopatologik organ hati dan ginjal tikus yang diinfeksi Staphylococcus aureus . Perlakuan VCO diberikan pada tikus dengan dosis $250 \mu \mathrm{L}$ secara oral selama 1 minggu. Infeksi $S$. aureus dilakukan secara intraperitoneal menggunakan kanul bengkok dengan dosis $5 \times 10^{2}$ sel bakteri. Penelitian ini menggunakan 20 ekor tikus Wistar betina umur 1 bulan dan dibagi menjadi 4 kelompok. Kelompok kontrol negatif (C-): tikus kontrol tanpa perlakuan; Kelompok AV: tikus diinfeksi dengan $S$. aureus dan diberi VCO; Kelompok VA: tikus diberi VCO terlebih dahulu kemudian diinfeksi dengan $S$. aureus; dan Kelompok kontrol positif (C+): tikus diinfeksi $S$. aureus tanpa pemberian VCO. Pada akhir percobaan semua tikus dieutanasi dan dinekropsi sesuai kode etik kesejahteraan hewan. Sampel plasma masing-masing perlakuan diambil untuk dilihat aktivitas SOD dan limfosit diisolasi dari limpa untuk diketahui kemampuan proliferasinya. Jaringan hati dan ginjal dikoleksi untuk pengamatan histopatologi. Hasil penelitian menunjukkan kelompok VA memiliki aktivitas SOD minggu ke-4 $(41.50 \pm 3.56 \%)$ dan proliferasi limfosit (0.3018) lebih tinggi dibanding semua perlakuan. Hati pada kelompok tritmen menunjukkan infiltrasi leukosit, tidak ada hemoragi (VA); sel hepatosit normal (VA). Ginjal pada kelompok tritmen menunjukkan infiltrasi leukosit (AV); epitel glomerulus dan tubulus normal, masih terdapat hemoragi (VA). Dari hasil penelitian ini menunjukkan bahwa VCO berpotensi sebagai imunomodulator, hepatoprotektan maupun nephroprotektan.
\end{abstract}

Kata Kunci: Virgin coconut oil, Staphylococcus aureus, Proliferasi limfosit, Superoxide dismutase, Hati, Ginjal

\section{ABSTRACT}

Widianingrum DC, Salasia SIO. 2021. Immunomodulatory effects of virgin coconut oil in wistar rats infected with Staphylococcus aureus JITV 26(1): 31-38. DOI: http://doi.dx.org/10.14334/jitv.v26i1.2670.

Virgin coconut oil (VCO) contains bioactive that induce immunity against infectious diseases. This study aim to determine the immunomodulatory effects of VCO based on the activity of superoxide dismutase (SOD), lymphocyte proliferation, and histopathological examination in liver and kidney of rats infected with Staphylococcus aureus. The VCO was given intragastrically to rats with a dose of $250 \mu \mathrm{L}$ for one week. The rats were infected with $S$. aureus at $5 \times 10^{2}$ bacterial cells intraperitoneally. Twenty (20) female Wistar rats of one month old were divided into four groups. The negative control group (C-): without treatment, AV group: infected with $S$. aureus followed by VCO treatment; VA group: pretreated with VCO followed by $S$. aureus infection, and positive control group $(\mathrm{C}+)$ : were infected with $S$. aureus without VCO. All rats were euthanized and necropsied based on the animal ethic standard. Plasma samples were taken to evaluate SOD activity, and lymphocytes were isolated from the spleen to determine their proliferative ability. Livers and kidneys were collected for a histopathology examination. Results showed that the VA group had the highest SOD activity on the $4^{\text {th }}$ week $(41.50 \pm 3.56 \%)$ and lymphocyte proliferation (0.3018) compared to all treatments, indicating immunomodulatory effects of VCO. Liver of treatments group showed leucocytes infiltration, no hemorrhages (VA); the hepatocytes with normal cells (VA). Kidney of treatments group showed leucocytes infiltration (AV); normal epithelial glomerulus and tubulus cells, still found hemorrhage (VA). These studies indicated that VCO has a potential role as an immunomodulator, hepatoprotectant, and nephroprotectant.

Key Words: virgin coconut oil, Staphylococcus aureus, superoxide dismutase, lymphocyte proliferation, liver, kidney

\section{INTRODUCTION}

Virgin coconut oil (VCO) is produced by natural processes either by fermentation, enzymatic (Silaban et al. 2014), centrifugation (Wong \& Hartina 2014), salination (Aziz et al. 2017), oil addition, step-wise heating, etc. (Pontoh et al. 2008). Elimination of refining, bleaching, and deodorizing stages preserve the 
essential content of VCO (Mansor et al. 2012). Medium-chain fatty acid (MCFA) consists lauric, caprylic, myristic, palmitic, palmitoleic, capric, stearic, and linoleic acids which are known as the essential content of VCO. The use of MCFA as antibacterial, antiviral, and antiprotozoal has been reported in several studies (Widianingrum et al. 2019a; Shilling et al. 2013; Yassen \& Khelkal 2015; Tangwatcharin \& Khopaibool 2012). The variety of MCFA in VCO depends on the material used. VCO contains lauric acid at 45.45 to $57.89 \%$ (Novarianto \& Tulalo 2020), 17\% myristic acid, $48 \%$ lauric acid, $8 \%$ caprylic acid, and $10 \%$ capric acid and may induce immunity (Fauzi et al. 2012). While the phenolic compounds of VCO around 49.56 to $59.88 \mu \mathrm{g} / \mathrm{mL}$ are known as antioxidants (Pulung et al. 2016).

Immunomodulatory effect of VCO could be identified by lymphocyte proliferation and enzymatic activity of superoxide dismutase (SOD) (Yuniwarti et al. 2012; Abujazia et al. 2012). Immune system reacted and responded simultaneously following the invasion or infection of foreign materials (Tizard 2000). Activity of free radical molecules, which are highly reactive, may cause an oxidative stress condition characterized by inactivation of antioxidant enzymes such as the SOD (El-Tohamy 2012). Usunomena et al. (2012) stated that there were three types of SOD in the body, namely: 1 . Copper-Zinc Superoxide Dismutase (Cu-ZnSOD), the main extracellular SOD found inside the cells; 2 . Manganese Superoxide Dismutase (Mn-SOD), synthesized in the cytoplasm, then sent into the mitochondria; 3. Extracellular Superoxide Dismutase (EC-SOD), a primary extracellular SOD found outside of the cells.

The essential oils of VCO will be absorbed and metabolized in the liver and excreted through the kidneys (Famurewa et al. 2019). The excretion of VCO is commonly through feces, sweat, and urine (Jim 2013). Abnormalities of liver and kidneys indicate the capability performance of these organs in metabolic process (Wang et al. 2013). Disruptions of both organs are commonly classified in several stages depend on the intensity of exposure (Lip et al. 2011). Low exposure may cause little or no morphological and functional changes, but higher intensity of exposure may significantly show pathological changes (Galus et al. 2013). Infection of Staphylococcus aureus (S. aureus) induces platelet aggregation and may retain in the hepatic sinusoids and glomeruli of kidneys. (Deppermann \& Kubes 2018; Surewaard et al. 2018). Accumulation injuries of these organs may lead to multi organs dysfunction (Guebre-Egziabher et al. 2013). Pathological changes could be caused by a single injury or multiple injuries and also by an acute to chronic damage (Ferenbach \& Bonventre 2016). Fibrosis is a pathological change in the liver characterized by progressive scar tissue formation in the liver parenchyma in response to wound healing (Pellicoro et al. 2014). Pathogenesis of fibrosis is initiated by parenchymal cell damage due to chronic injury and inflammation (Hernandez-Gea \& Friedman 2011). Prolonged fibrosis may develop to the formation of cirrhosistic liver. If the primary cause of injury is elliminated, the fibrosis is generally reversible (Koyama \& Brenner 2017). Several factors that determine the reversibility of fibrosis include the total amount of collagen, the duration of fibrosis, and the presence of extracellular matrix destroying enzymes (Albanis \& Friedman 2006). The presence of congestion may also be seen in fibrosis characterised by reddish colour and dilation of capillaries containing blood cells (Sujono et al. 2015). Mild congestion is generally reversible but it may become irreversible when the injury is getting worse (Chung et al. 2016).

On the other hand, cirrhosis is irreversible due to the cross-linking of collagen by tissue transglutaminase, which is difficult to degrade the extracellular matrix scar tissue (Pellicoro et al. 2012; Sohrabpour et al. 2012). Cirrhosis is known as the 14th most common cause of death worldwide. The early therapeutic is a new concept to prevent complications of cirrhosis to avoid or delay clinical decompensation reduce mortality (Tsochatzis et al. 2014).

The infection of $S$. aureus may affect various organs, including liver, spleen, kidneys and skin. (Felistiani 2017; Lucas et al. 2012; Fauzi et al. 2012). Kidneys are commonly vulnerable to $S$. aureus infections (Pollitt et al. 2018) that may cause abscess (Rauch et al. 2012), fatty degeneration, hydropic degeneration and necrosis (Suhita et al. 2013). The previous study reported that the VCO could be used as a ruminant supplement to protection an undegradable agent in rumen as formaldehyde (Widianingrum et al. 2019b). The purpose of this study is to determine the immunomodulatory effect of VCO based on the activity of SOD, lymphocyte proliferation, and histopathological examination of liver and kidney of rats infected with $S$. aureus.

\section{MATERIALS AND METHODS}

This experiment was approved by The Ethics Committee of Central Laboratory LPPT UGM with a number of 333/ KEC-LPPT/X/2015. A total number of 20 female Wistar rats of 1 month old, was provided by the UP2KH UGM and was adopted for 1 week before treatment. Rats were infected with $S$. aureus of $5 \times 10^{2}$ bacteria intraperitoneally (Fauzi et al. 2012). The VCO (MIPA UGM) was given orally with a dose rate of 250 
$\mu \mathrm{L} /$ rat daily for 1 week consecutively. The treatment consists of four groups with 5 replications: 1) Group C(negative control): rats were given orally with phosphate buffer saline (PBS) for a week without $S$. aureus infection; 2) Group AV: rats were infected with $S$. aureus followed by VCO; 3) Group VA: rats were previously treated with VCO followed by $S$. aureus infection; 4) Group C+ (positive control): rats were infected with $S$. aureus followed by PBS orally for a week consecutively in daily basis.

At the end of experiment, all rats were euthanized and necropsied for pathological examination. Lymphocytes were isolated from the spleen of each experimental rat at the end of the study. Spleen were injected with $3 \mathrm{~mL}$ of RPMI and then chopped in a sterile tube. The solution was centrifuged at 3,000 rpm for 5 minutes, $2 \mathrm{~mL}$ of $\mathrm{NH}_{4} \mathrm{Cl}$ was added to lyse erythrocytes. After centrifugation at 3,000 rpm for 5 minutes, the pellets were taken and added with $1 \mathrm{~mL}$ of complete media. Lymphocytes were counted with a hemocytometer and determined their viability with trypan blue $\left(1 \times 10^{6} / \mathrm{mL}\right)$. A total of $100 \mu \mathrm{L}$ of lymphocyte cells were added with $100 \mu \mathrm{L}$ of complete media then placed on the microplate and incubated at $37^{\circ} \mathrm{C}$ for 72 hours with $5 \% \mathrm{CO}_{2}$. The solution was added with $10 \mu \mathrm{L}$ MTT and then incubated at $37^{\circ} \mathrm{C}$ for 4 hours with $5 \% \mathrm{CO}_{2}$. The suspension was added with $100 \mu \mathrm{L}$ SDS and incubated overnight at room temperature. The proliferation of lymphocytes was measured using an ELISA reader at 550-600 nm (ACTG Laboratory Technologist Committee 2000).

Plasma samples were obtained to determine superoxide dismutase (SOD) activity by collecting the blood of treated rat with $10 \%$ ethylene diamine tetraacetic acid (EDTA). The SOD activity was tested using a commercial kit according to the standard instructions for use (StressMarq, Biosciences, Canada). The principle of determining the antioxidant activity of SOD is known as the ability of SOD to catalyze superoxide anion $\left(\mathrm{O}_{2}-\right)$ into molecular hydrogen peroxide and oxygen (Khachatryan et al. 2011). All samples were incubated at room temperature for 20 minutes, and then the absorbance was calculated using a UV spectrophotometer (Shimidzhu UV-Visible 1601 Type) at a wavelength of $450 \mathrm{~nm}$.

$$
\% \text { Inhibiton }=\frac{\text { Mean OD sampel }}{\text { mean OD zero standard }} \times 100 \%
$$

Samples of liver and kidneys were collected from each rat, fixed in formalin $10 \%$, and stained with hematoxylin-eosin for histopathological examination based on Suhita et al. (2013) method. The tissue was observed under a Zeiss binocular microscope at a magnification of 40x. The histopathological changes of the organs were reported descriptively.

\section{RESULTS AND DISCUSSION}

Based on the lymphocyte proliferation (Figure 1), the rat treated with VCO had higher lymphocyte proliferation. The group of rats given VCO before $S$. aureus infection (0.3018) had the most significant increased lymphocyte proliferation compared to rats given VCO after $S$. aureus infection (0.2641) and the control group (C+: 0.2170; C-: 0.2317).

The VCO-pretreated rats (VA) appeared to induce highest lymphocyte proliferation compared to other groups of rats. Results showed that VCO may induce

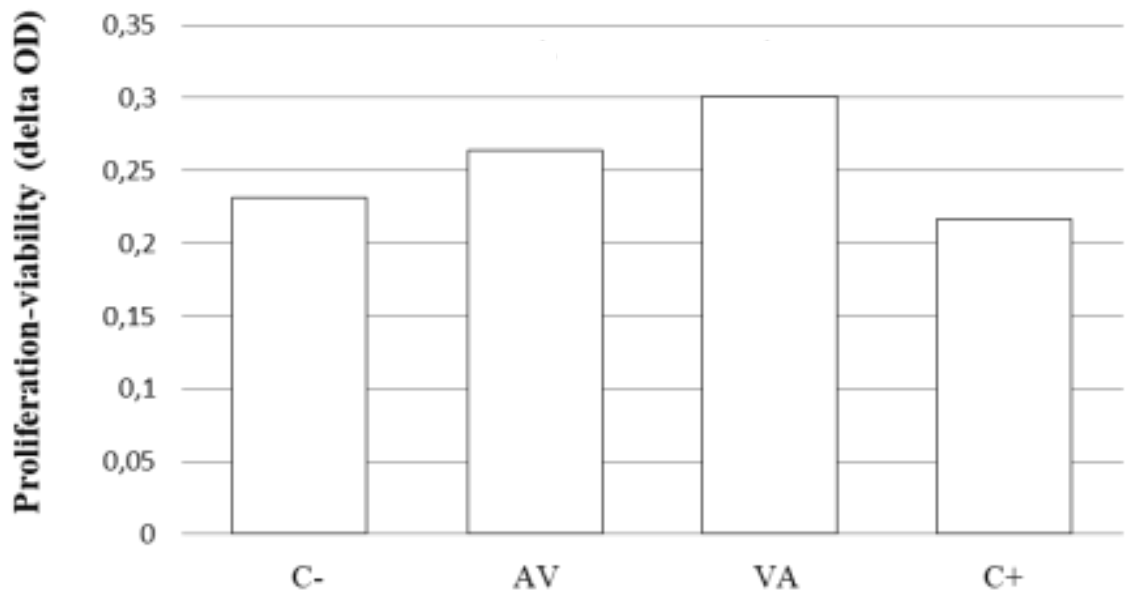

Figure 1. Lymphocyte proliferation in treated rats. Lymphocyte proliferation was seen by the color changes that are observed under the ELISA reader, the higher the absorbance value indicated that the higher activity the lymphocyte proliferation. The negative control group (C-): without treatment, AV group: infected with S. aureus followed by VCO treatment; VA group: pretreated with VCO followed by S. aureus infection, and positive control group (C+): were infected with S. aureus without VCO 
Table 1. Percent inhibition of SOD activity in treated rats

\begin{tabular}{|c|c|c|c|c|}
\hline SOD Activity & $\mathrm{C}-$ & AV & VA & $\mathrm{C}+$ \\
\hline & \multicolumn{4}{|c|}{ (2) \% } \\
\hline Week I & $36.10 \pm 0.79$ & $37.81 \pm 0.64$ & $38.21 \pm 1.19$ & $35.44 \pm 2.28$ \\
\hline Week II & $38.27 \pm 1.21$ & $36.63 \pm 1.16$ & $38.14 \pm 2.59$ & $44.93 \pm 7.03$ \\
\hline Week III & $34.19 \pm 0.79^{b}$ & $31.36 \pm 1.09^{\mathrm{ab}}$ & $29.58 \pm 1.68^{\mathrm{a}}$ & $41.37 \pm 0.82^{c}$ \\
\hline Week IV & $29.78 \pm 1.40^{\mathrm{a}}$ & $30.69 \pm 1.79^{\mathrm{a}}$ & $41.50 \pm 3.56^{b}$ & $31.75 \pm 0.99^{\mathrm{a}}$ \\
\hline
\end{tabular}

The difference in notation shows a significant difference at the $5 \%$ confidence level ( $\mathrm{p}<0.05)$.

The negative control group (C-): without treatment, AV group: infected with $S$. aureus followed by VCO treatment; VA group: pretreated with VCO followed by $S$. aureus infection, and positive control group $(\mathrm{C}+)$ : were infected with $S$. aureus without VCO.

the infection of $S$. aureus has better effect on lymphocyte proliferation than that of post infection. These results indicated that the VCO may induce immunomodulation. The treatment could modulate lymphocyte proliferation (Yuniwarti et al. 2012), increasing antibody titers, macrophage phagocytosis activity, lymphocyte count, $\mathrm{CD}_{4}, \mathrm{CD}_{8}$, heterophils, and body weight (Yuniwarti et al. 2012).

Results of SOD activity (\% inhibition) of each treatment are presented in Table 1. Based on the observations, the SOD activity at week 1 and week 2 were not significantly different among the treated rats. At week-1 of treated rats shows that the SOD responses were homogenous and the activity of SOD was not significantly different. A significant increase of SOD activity was noted when VCO was given prior to $S$. aureus infection (VA) at week $4(41.50 \%)$. This result confirms that VCO treatment has best immunomodulation response in rats when VCO was given before $S$. aureus infection.

Dauqan et al. (2012) reported that the activity of SOD of coconut oil increased from week 4 and remained high until week 8 . The coconut oil appear to have highest activity of SOD compared to both palm oil and corn oil. Nevin \& Rajamohan (2006) also reported that antioxidant level of rats pretreated with VCO showed an increase in activity of catalase (CAT) and superoxide dismutase (SOD). In their study, the lipid peroxide levels of the liver and kidneys in the VCO treatment were significantly lower than other pretreatments. They knew that VCO increases the total glutathione (GTN), which is known as a sensitive indicator of antioxidant status. Both enzymes are known to induce the mechanisms of defense against reactive oxygen species (ROS) and to prevent lipid peroxidation (Bolin et al. 2010).

Microscopic changes of liver and kidney of treated rats are shown in Figure 2 and 3. There were no changes of liver in the negative control (untreated rats) (Figure 2A). Liver of rats infected with $S$. aureus showed nucleus enlargement with chromatin defragmentation, infiltration of leucocytes, hemorrhages (Figure 2B). Liver of rats treated with $\mathrm{VCO}$ at $250 \mu \mathrm{L} /$ day after $S$. aureus infection showed leucocytes infiltration, however there were no hemorrhages (Figure 2C). Liver of rat pretreated with VCO followed by $S$. aureus infection showed the hepatocyte with normal cells (Figure 2D). The microscopic changes reveal that the VCO may induce immune system against infectious agents and modulate the cell damages (Senin et al. 2018). Bartz et al. (2011) reported that intraperitoneal dosing of $S$. aureus to rats may affect liver oxidative mtDNA and mtDNA content as well as increase mitochondrial OGG1 protein and enzymatic activity. Increasing or OGG1 indicates mitochondrial response during sepsis.

The present study shows that pretreatment of VCO prior to $S$. aureus infection (VA) may prevent or reduce liver damage. Microscopically, hepatic regeneration of VA developed better than AV group. VCO may also increase immunity against bacterial infection as shown in lymphocyte proliferation. Essential oil of fatty acids increases immunity capacity by improving metabolism and increasing the SOD level. The MCFA content has also been reported to inhibit complications in diabetic patients (Sheela et al. 2017), reducing risks in cardiovascular diseases and cancer (Narayanankutty et al. 2018), increasing high-density lipoprotein (HDL) (Chinwong et al. 2017). The mechanisms of regeneration in VCO treatment could be due to lymphocyte proliferation by releasing opsonin to induce macrophages, increase superoxide dismutase (SOD) activity, antibacterial effect by breaking the cell walls of $S$. aureus (Widianingrum et al. 2017).

Kidneys of the negative control (untreated rats) were normal with glomerular cells surrounded by squamous epithelial cells and tubules were surrounded by cuboid epithelial cells (Figure 3A). Kidneys of rats infected with $S$. aureus showed infiltration of leucocytes, hemorrhages (congestion), tubular necrosis 


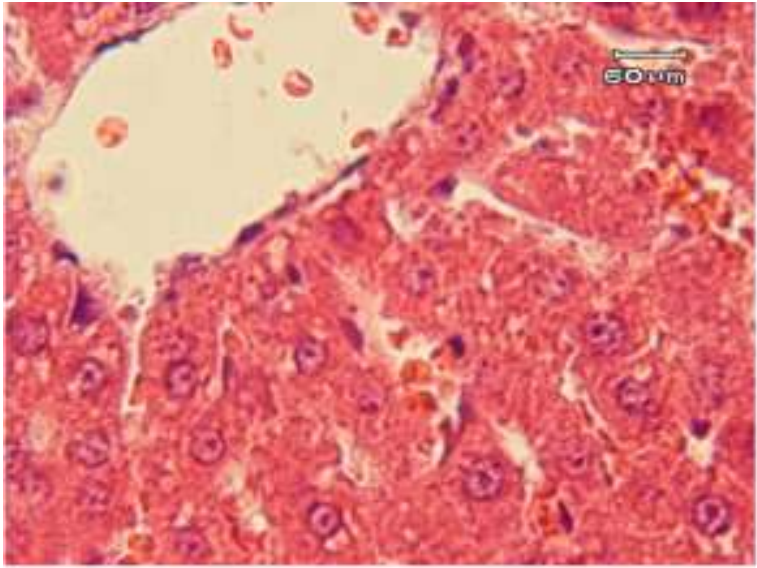

A

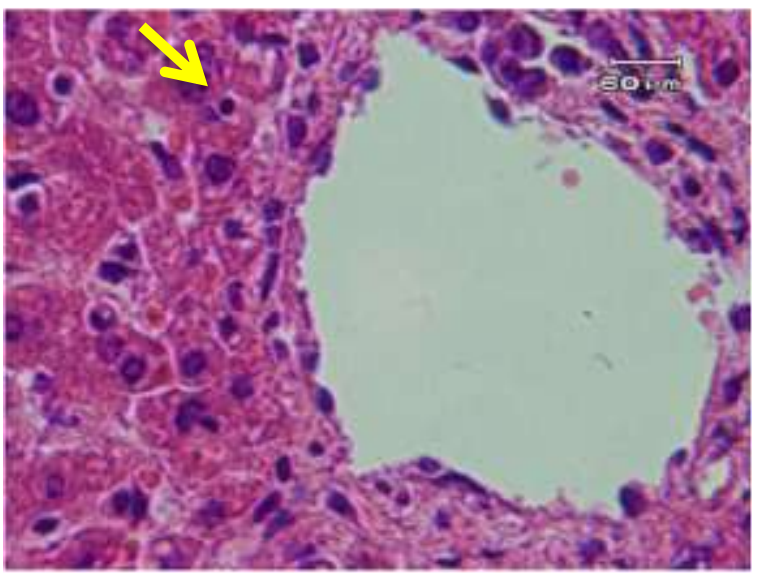

C

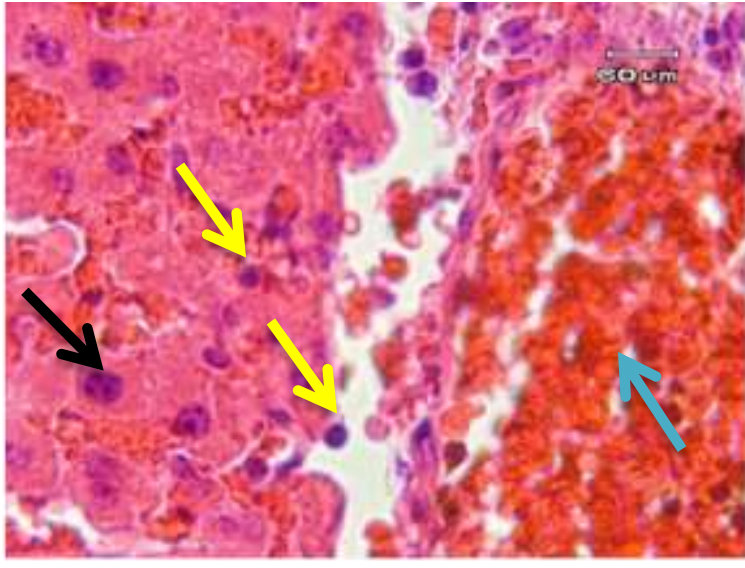

B

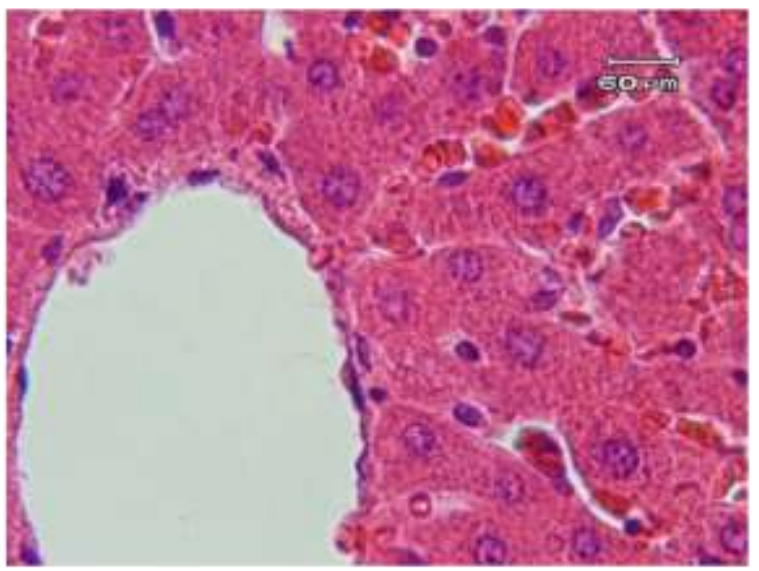

D

Figure 2. Histopathology of the liver (H\&E, 40x magnification). A. Normal liver of the untreated rat, polyhedral hepatocytes with nucleus centrally and narrowed sinusoids; B. Liver of rat infected with $S$. aureus enlarged nucleus with chromatin defragmentation (black arrow), infiltration of leucocytes (yellow arrow), haemorrhages (blue arrow); C. Liver of rat treated with VCO at $250 \mu \mathrm{L} /$ day after $S$. aureus infection showed vacuolitation cell; D. Liver of rats pretreated with VCO followed by S. aureus infection showed the hepatocytes with normal configuration.

immunity responses. The pretreatment of VCO prior to (Figure $3 \mathrm{~B}$ ). Kidney of rat treated with VCO at 250 $\mu \mathrm{L} /$ day after $S$. aureus infection showed leucocytes infiltration (Figure 3C). Kidney of rats pretreated with VCO followed by $S$. aureus infection showed normal epithelial glomerulus and tubulus cells, however still found hemorrhage (Figure 3D). Regeneration of kidneys was mediated by a combination of direct VCO treatment and a complex metabolic mechanisms (Fernando et al. 2015; Rajamohan \& Archana 2018). Rats that were dosed with monolaurin known as an essential substance of VCO for one week before $S$. aureus infection caused 50\% survival rate of rats (Manohar et al. 2013). The most powerfull contain of VCO is lauric acid (Novarianto \& Tulalo 2020). Monolaurin is monoglycerin which is obtained from lauric acid from VCO (Tangwatcharin \& Khopaibool
2012). In the Manohar et al. (2013) study, the highest survival rate was found when VCO treatment was mixed with vancomycin. The bacterial infections were not detected in kidneys of the surviving rats after 30 days. The VCO treatments were also reported to affects kidney by increasing glutathione reductase and decreasing catalase (Đurašević et al. 2019). The degenerative and destructive effects in kidneys may be prevented, regenerated, and restored by providing VCO (Akinnuga et al. 2019). Restoration of kidneys is a modulation mechanism between antioxidants and antiinflammation of VCO (Kamisah et al. 2016; Famurewa et al. 2017).

Leucocytes like neutrophils contain enzymes that digest proteins. A high number of activated neutrophils may cause damage to the surrounding tissue, not just the site of the original damage. Inflammation of vessel 


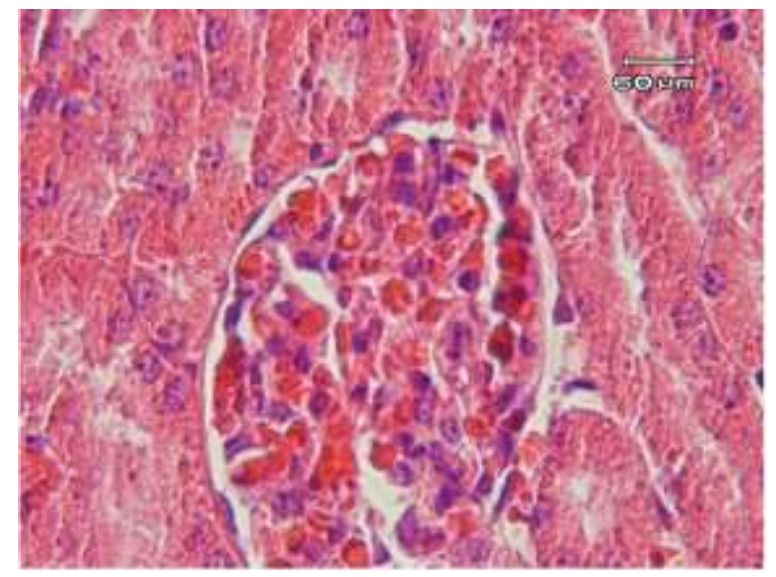

A

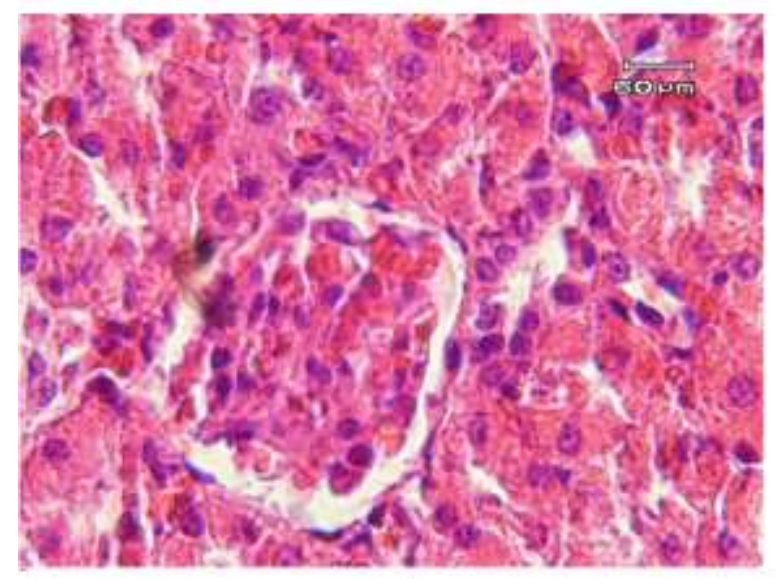

$\mathrm{C}$

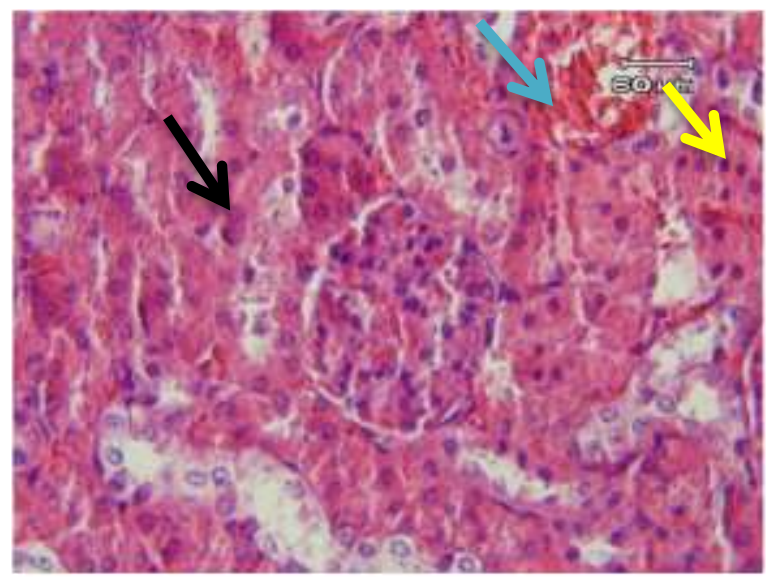

B

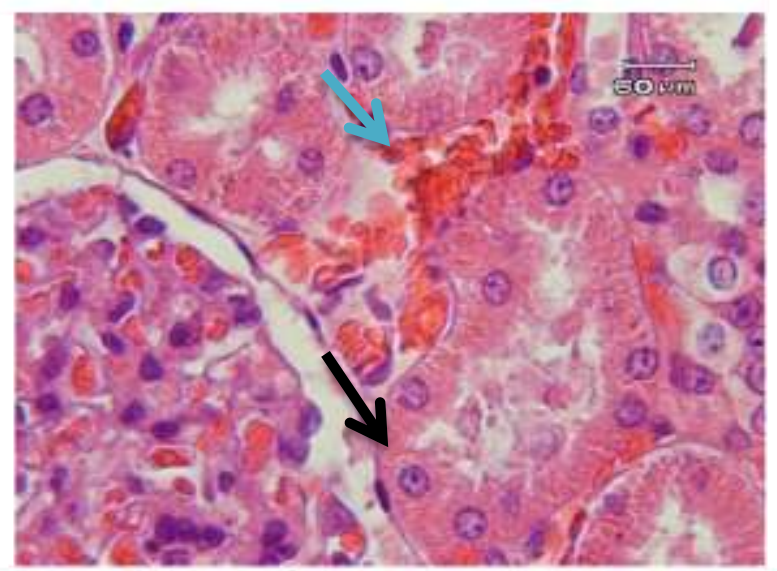

D

Figure 3. Histopathology of the kidneys (H\&E, 40x magnification). A: Normal kidney of the untreated rat, B. Kidney of rat infected with $S$. aureus showed infiltration of leucocytes (yellow arrow), hemorrhages (blue arrow), tubular necrosis (black arrow); C. Kidney of rat treated with VCO at $250 \mu \mathrm{L} /$ day after $S$. aureus infection, tend to normal; D. Kidney of rats pretreated with VCO followed by $S$. aureus infection showed hemorrhages (blue arrow), normal epithelial tubulus and glomerulus cells (black arrow)

walls (vasculitis), one of the harmful effect of acute inflammation, can cause excessive leakiness of blood vessels, hemorrhage, and can impair blood supply to tissue, causing ischaemia and infarction (Brooks 2010).

\section{CONCLUSION}

VCO has shown a potential role in immunomodulation and modulation mechanisms to repairing lesions of liver and kidneys due to Staphylococcus aureus infection.

\section{REFERENCES}

Abujazia MA, Muhammad N, Shuid AN, Soelaiman IN. 2012. The effects of Virgin Coconut Oil on bone oxidative status in ovariectomised rat. Evidence-Based Complement Altern Med. 2012:1-6.

ACTG Laboratory Technologist Committee. 2000. ACTG Lab Man Lymphocyte Proliferation Assay. Version 1.0.
Akinnuga AM, Bamidele O, Adewumi AJ. 2019. Evaluation of kidney function parameters in diabetic rats following Virgin Coconut Oil diet. Folia Med (Plovdiv). 61:249257.

Albanis E, Friedman SL. 2006. Antifibrotic agents for liver disease. Am J Transplant. 6:12-19.

Aziz T, Olga Y, Puspita Sari A. 2017. Pembuatan Virgin Coconut Oil (VCO) Dengan Metode Penggaraman. J Tek Kim. 23:129-136.

Bartz RR, Suliman HB, Fu P, Welty-Wolf K, Carraway MS, MacGarvey NC, Withers CM, Sweeney TE, Piantadosi CA. 2011. Staphylococcus aureus Sepsis and mitochondrial accrual of the 8-Oxoguanine DNA glycosylase DNA repair enzyme in mice. Am J Respir Crit Care Med. 183:226-233.

Bolin AP, Macedo RC, Marin DP, Barros MP, Otton R. 2010. Astaxanthin prevents in vitro auto-oxidative injury in human lymphocytes. Cell Biol Toxicol. 26:457-467.

Brooks H. 2010. Inflamation. In: Gen Pathol Vet Nurses. Malaysia: Wiley-Blackwell; p. 52-55. 
Chinwong S, Chinwong D, Mangklabruks A. 2017. Daily consumption of virgin coconut oil increases highdensity lipoprotein cholesterol levels in healthy volunteers: A randomized crossover trial. EvidenceBased Complement Altern Med. 2017:1-8.

Chung DJ, Sung K, Osuagwu FC, Wu HH, Lassman C, Lu DSK. 2016. Contrast enhancement patterns after irreversible electroporation: experimental study of CT perfusion correlated to histopathology in normal porcine liver. J Vasc Interv Radiol. 27:104-111.

Dauqan EM, Abdullah A, Abdullah H. 2012. Effect of Different Concentrations of Red Palm Olein and Different Vegetable Oils on Antioxidant Enzymes in Normal and Stressed Rat. In: Antioxid Enzym. London (UK): InTech; p. 303.

Deppermann C, Kubes P. 2018. Start a fire, kill the bug: The role of platelets in inflammation and infection. Innate Immun. 24:335-348.

Đurašević S, Jasnić N, Prokić M, Grigorov I, Martinović V, Đorđević J, Pavlović S. 2019. The protective role of virgin coconut oil on the alloxan-induced oxidative stress in the liver, kidneys and heart of diabetic rats. Food Funct. 10:2114-2124.

El-Tohamy MM. 2012. The mechanisms by which oxidative stress and free radical damage produces male infertility. Life Sci J. 9:674-688.

Famurewa AC, Aja PM, Maduagwuna EK, EkelemeEgedigwe CA, Ufebe OG, Azubuike-Osu SO. 2017 Antioxidant and anti-inflammatory effects of Virgin Coconut Oil supplementation abrogate acute chemotherapy oxidative nephrotoxicity induced by anticancer drug methotrexate in rats. Biomed Pharmacother. 96:905-911.

Famurewa AC, Ugwu-Ejezie CS, Iyare EE, Folawiyo AM, Maduagwuna EK, Ejezie FE. 2019. Hepatoprotective effect of polyphenols isolated from Virgin Coconut Oil against sub-chronic cadmium hepatotoxicity in rats is associated with improvement in antioxidant defense system. Drug Chem Toxicol.:1-9.

Fauzi A, Setiawan I, Ariyanti F. 2012. The effect of Virgin Coconut Oil (VCO) on Staphylococcus aureus infection in mice (Mus musculus) observed from different organ histopatholog. J Appl Sci Res. 8:1168-1173.

Felistiani V. 2017. Uji aktivitas ekstrak etanol biji alpukat (Persea americana Mill.) terhadap gambaran histopatologi hepar dan limpa pada mencit (Mus musculus) yang diinfeksi Staphylococcus aureus. malang (Indones): The State Islamic University of Maulana Malik Ibrahim.

Ferenbach DA, Bonventre J V. 2016. Acute kidney injury and chronic kidney disease: From the laboratory to the clinic. Néphrologie \& Thérapeutique. 12:S41-S48.

Fernando W, Martins IJ, Goozee K, Brennan CS, Jayasena V, Martins R. 2015. The role of dietary coconut for the prevention and treatment of Alzheimer's disease: potential mechanisms of action. Br J Nutr. 114:1-14.
Galus M, Kirischian N, Higgins S, Purdy J, Chow J, Rangaranjan S, Li H, Metcalfe C, Wilson JY. 2013. Chronic, low concentration exposure to pharmaceuticals impacts multiple organ systems in zebrafish. Aquat Toxicol. 132-133:200-211.

Guebre-Egziabher F, Alix PM, Koppe L, Pelletier CC, Kalbacher E, Fouque D, Soulage CO. 2013. Ectopic lipid accumulation: A potential cause for metabolic disturbances and a contributor to the alteration of kidney function. Biochimie. 95:1971-1979.

Hernandez-Gea V, Friedman SL. 2011. Pathogenesis of liver fibrosis. Annu Rev Pathol Mech Dis. 6:425-456.

Jim E. 2013. Metabolisme lipoprotein. J Biomedik. 5:149156.

Kamisah Y, Ang S-M, Othman F, Nurul-Iman BS, Qodriyah HMS. 2016. Renoprotective effect of Virgin Coconut Oil in heated palm oil diet-induced hypertensive rats. Appl Physiol Nutr Metab. 41:1033-1038.

Khachatryan L, Vejerano E, Lomnicki S, Dellinger B. 2011. Environmentally persistent free radicals (EPFRs). 1. Generation of reactive oxygen species in aqueous solutions. Environmental science \& technology. 45(19): 8559-8566.

Koyama Y, Brenner DA. 2017. Liver inflammation and fibrosis. J Clin Invest. 127:55-64

Lip GY, Frison L, Halperin JL, Lane DA. 2011. Comparative Validation of a novel risk score for predicting bleeding risk in anticoagulated patients with atrial fibrillation. $\mathrm{J}$ Am Coll Cardiol. 57:173-180.

Lucas SB, Zaki SR, Portmann BC. 2012. Other viral and infectious diseases and HIV-related liver disease. In: MacSween's Pathol Liver. Amsterdam (NL): Elsevier; p. $403-466$.

Manohar V, Echard B, Perricone N, Ingram C, Enig M, Bagchi D, Preuss HG. 2013. In vitro and in vivo effects of two coconut oils in comparison to monolaurin on Staphylococcus aureus: Rodent studies. J Med Food. 16:499-503.

Mansor TST, Che Man YB, Shuhaimi M, Abdul Afiq MJ, Ku Nurul FKM. 2012. Physicochemical properties of Virgin Coconut Oil extracted from different processing methods. Int Food Res J. 19:837-845.

Narayanankutty A, Illam SP, Raghavamenon AC. 2018. Health impacts of different edible oils prepared from coconut (Cocos nucifera): A comprehensive review. Trends Food Sci Technol. 80:1-7.

Nevin KG, Rajamohan T. 2006. Virgin Coconut Oil supplemented diet increases the antioxidant status in rats. Food Chem. 99:260-266.

Novarianto H, Tulalo M. 2020. Kandungan asam laurat pada berbagai varietas kelapa sebagai bahan baku VCO. J Penelit Tanam Ind. 13:28.

Pellicoro A, Ramachandran P, Iredale JP. 2012. Reversibility of liver fibrosis. Fibrogenesis Tissue Repair. 5:S26. 
Pellicoro A, Ramachandran P, Iredale JP, Fallowfield JA. 2014. Liver fibrosis and repair: immune regulation of wound healing in a solid organ. Nat Rev Immunol. 14:181-194.

Pollitt EJG, Szkuta PT, Burns N, Foster SJ. 2018. Staphylococcus aureus infection dynamics.Prince A, editor. PLOS Pathog. 14:e1007112.

Pontoh J, Br Subakti M, Papilaya M. 2008. Kualitas virgin coconut oil dari beberapa metode pembuatan. Chem Prog. 1:60-65.

Pulung ML, Yogaswara R, Sianipar FRD. 2016. Potensi antioksidan dan antibakteri virgin coconut oil dari tanaman kelapa asal Papua. Chem Prog. 9:63-69.

Rajamohan T, Archana U. 2018. Nutrition and Health Aspects of Coconut. In: Coconut Palm (Cocos nucifera L) - Res Dev Perspect. Singapore: Springer Singapore; p. 757777.

Rauch S, DeDent AC, Kim HK, Bubeck Wardenburg J, Missiakas DM, Schneewind O. 2012. Abscess formation and alpha-hemolysin induced toxicity in a mouse model of Staphylococcus aureus peritoneal infection. Weiser JN, editor. Infect Immun. 80:37213732 .

Senin MM, Al-Ani IM, Mahmud MIAM, Muhammad N, Kasmuri HM. 2018. Protective effect of virgin coconut oil on cyclophosphamide-induced histological changes in lymphoid tissues. IIUM Med J Malaysia. 17:65-74.

Sheela DL, Nazeem PA, Narayanankutty A, Shylaja RM, Davis SP, James P, Valsalan R, Devassy Babu T, Raghavamenon AC. 2017. Coconut phytocompounds inhibits polyol pathway enzymes: Implication in prevention of microvascular diabetic complications. Prostaglandins, Leukot Essent Fat Acids. 127:20-24.

Shilling M, Matt L, Rubin E, Visitacion MP, Haller NA, Grey SF, Woolverton CJ. 2013. Antimicrobial effects of Virgin Coconut Oil and its medium-chain fatty acids on Clostridium difficile. J Med Food. 16:1079-1085.

Silaban R, Manullang RS, Hutapea V. 2014. Pembuatan Virgin Coconut Oil (VCO) melalui kombinasi teknik fermentasi dan enzimatis menggunakan ekstrak nenas. J Pendidik Kim. 6:91-99.

Sohrabpour AA, Mohamadnejad M, Malekzadeh R. 2012. Review article: the reversibility of cirrhosis. Aliment Pharmacol Ther. 36:824-832.

Suhita NLPR, Sudira IW, Winaya IBO. 2013. Histopatologi ginja; tikus putih akibat pemberian ekstrak pegagan (Centella asiatica) peroral. Bul Vet Udayana. 5:71-78.
Sujono TA, Wahyuni AS, Da'i M, Kusumowati ITD, Suhendi A, Munawaroh R, Pratiwi N, Fauziyyah S, Rahadini R, Lestari S. 2015. Pengaruh pemberian ekstrak etanol Meniran (Phyllanthus niruri L) selama 90 hari terhadap fungsi hati tikus. In: Univ Res Colloq. p. 136-142.

Surewaard BG, Thanabalasuriar A, Zeng Z, Tkaczyk C, Cohen TS, Bardoel BW, Jorch SK, Deppermann C, Bubeck Wardenburg J, Davis RP, et al. 2018. $\alpha$-toxin induces platelet aggregation and liver injury during Staphylococcus aureus sepsis. Cell Host Microbe. 24:271-284.e3.

Tangwatcharin P, Khopaibool P. 2012. Activity of virgin coconut oil, lauric acid or monolaurin in combination with lactic acid against Staphylococcus aureus. Southeast Asian J Trop Med Public Health. 43:969-985.

Tizard I. 2000. Immunology: An Introduction. 6th ed. New York (USA): Saunders College Publishing.

Tsochatzis EA, Bosch J, Burroughs AK. 2014. Liver cirrhosis. Lancet. 383:1749-1761.

Usunomena U, Ademuyiwa AJ, Tinuade OO, Uduenevwo FE, Martin O, Okolie NP. 2012. N-nitrosodimethylamine (NDMA), liver function enzymes, renal function parameters and oxidative stress parameters: A review. Br J Pharmacol Toxicol. 3:165-176.

Wang W, Wu Z, Dai Z, Yang Y, Wang J, Wu G. 2013. Glycine metabolism in animals and humans: implications for nutrition and health. Amino Acids. 45:463-477.

Widianingrum D, Salasia SIO, Indarjulianto S, Noviandi CT, Anim M. 2017. Potensi imunomodulator virgin coconut oil (VCO) sebagai suplemen pakan terhadap infeksi Staphylococcus aureus penyebab mastitis subklinis pada kambing. Yogyakarta (Indones): Gadjah Mada University.

Widianingrum DC, Noviandi CT, Salasia SIO. 2019. Antibacterial and immunomodulator activities of Virgin Coconut Oil (VCO) against Staphylococcus aureus. Heliyon. 5:e02612.

Wong Y, Hartina H. 2014. Virgin Coconut Oil Production by Centrifugation Method. Orient J Chem. 30:237-245.

Yassen LT, Khelkal IN. 2015. Effect of some fatty acids on virulence factors of Proteus mirabilis. IJABR. 5:108117.

Yuniwarti EYW, Asmara W, Artama WT, Tabbu CR. 2012. The effect of Virgin Coconut Oil on lymphocyte and CD4 in chicken vaccinated against Avian Influenza virus. J Indones Trop Anim Agric. 37:64-69. 